\title{
Terminology-Based Indonesian Language Teaching Materials Development: ISTIQLAL High School Context
}

\author{
Susy Deliani ${ }^{1}$, Edi Yanto ML $^{2}$, Al Kausar Lingga ${ }^{3}$, Hakim Prasasti Lubis ${ }^{4}$, \\ Enda Tarigan ${ }^{5}$, Nunung Susilo Putri ${ }^{6}$ \\ 1, 2,3 Universitas Muslim Nusantara Al-Wasliyah, Medan, Indonesia \\ ${ }^{4}$ SMAS YPK Medan, \\ ${ }^{5}$ SMA ISTIQLAL, Deli Serdang, \\ ${ }^{6}$ Universitas Lancang Kuning. Pekanbaru \\ susi_deliani@yahoo.com
}

\begin{abstract}
ARTICLE HISTORY
Received : 2019-06-11

Revised : 2019-06-13

Accepted : 2019-06-20
\end{abstract}

\section{KEYWORDS}

Teaching materials Terminology-based 2013 curriculum.

High School

\begin{abstract}
This ongoing study aims to share insight result in its initial stage by find out (1) Types of teaching material regarding terminology-based Indonesian language materials, (2) Most criteria for good teaching materials, and (3) Definition of most common terms regarding terminology-based Indonesian language materials. The subjects of this study were content experts, Indonesian language subject teachers, and students of ISTIQLAL High School Deli Serdang. The procedure of this study adapted research procedures from Borg and Gall in its initial stages. The instruments used for data collection in this study were school documentation and internet library research. Data analysis techniques applied in this study were qualitative and quantitative techniques. The results of this study indicate that: (1) teaching materials are should be designed in line with the 2013 curriculum based on printed, video and audio material, (2) the criteria should highlighted the essence of relevance, readability, and systematic (3) There are 16 related terms issues were reveals regarding Language teaching material revealed in this study.
\end{abstract}

\section{Introduction}

The research on the development of teaching materials aims to describe. Development of terminology-based Indonesian language materials, validity of terminology-based Indonesian language teaching materials, constraints faced in developing terminology-based Indonesian language teaching materials Teaching materials are a set of materials that are arranged systematically both written and not so as to create an environment / atmosphere that allows students to learn (Ministry of National Education, 2008). This definition implies the existence of a material arranged in such a way as to help students learn well. The development of teaching materials is an activity to bring up teaching materials that are by the demands of the curriculum. The development of teaching materials is intended to provide teaching materials by the characteristics of students to solve problems (Ministry of National Education, 2008). Thus, the development of teaching materials is important to meet the scarcity of needed teaching materials (Hasibuan et al., 2018).

Mulyasa (2006) also explained that teaching material is one part of learning resources that can be interpreted as something that contains a message of learning, both specifically intended and general that can be used for learning purposes. In other words, teaching materials are all forms of material used to help teachers/instructors in carrying out classroom learning activities. The material in question can be either written material or unwritten material.

Teaching materials have a systematic structure and sequence, explain the instructional objectives to be achieved, motivate students to learn, anticipate the difficulty of learning of students so that it provides guidance for students to study the material, provide a lot of training, provide summaries, and are generally oriented on individual learners (learner-oriented). Usually, teaching material is independent, meaning that students can learn it independently because it is systematic and complete.

\section{Method}

The development of this teaching material uses a research and development design. The procedure of this study adapted the development research procedures presented by Borg and Gall (1989). This procedure includes preliminary research, planning (planning and validation), development of teaching materials, early-stage field trials, revision of teaching materials, trial use of the main field, revision of teaching materials. The subjects of this study were experts on the content of teaching materials, Indonesian language teachers, and students of class X and XI ISTIQLAL High School in 2018/2019.

Preliminary research was conducted to collect and identify information related to the problems encountered in learning. At the planning stage, the 
things done by researchers cover the preparation of teaching materials and expert testing on a small scale. In the preparation stage of teaching materials, RPP syllabus, and teaching materials possessed by Indonesian language subject teachers are collected to determine the material of teaching materials to be compiled. In the steps of gathering information, the literature is used in the preparation of teaching materials. In this step the formulation of skills and expertise and expertise related to the problem is also carried out, determining the objectives to be achieved at each stage, and if possible / needed to carry out a limited feasibility study.

Activities carried out at the drafting stage are compiling terminology-based Indonesian language materials. Matters included in teaching materials, namely the identity of teaching materials (title, chapter, basic competencies, indicators), subject matter, summary, and final evaluation of the lesson. Teaching materials that have been compiled by researchers are then validated by experts. This trial was conducted to determine the validity of teaching materials that have been designed based on the rational thinking of experts. The content expert teaching materials are asked to validate the design of the teaching material contents.

In this initial trial, the design of instructional materials was validated by experts, then tested to students. Because of the initial field trials. So this early stage field trial is still on a limited scale, involving subjects of nine students who have diverse learning achievements. This is conducted to get more valid results because it has been represented by students who have diverse Indonesian language learning achievements. In addition to students, it also involves one Indonesian language subject teacher. In this step, data collection and analysis can be conducted by interview, observation and questionnaire. In the revision of teaching materials, what is done is to improve the initial product. This repair is very likely to be done more than once, according to the results shown in the limited trial, so that the main product (model) draft is obtained.

This limited trial reflects all students who are the subject of this research. In this stage, the effectiveness of the teaching materials that have been prepared is also tested. This is done to determine the success rate of developing teaching materials in terms of the completeness of the subject matter contained in the teaching material.

In this revision of teaching materials, the researcher made improvements/improvements to the results of the wider trial, so that the product developed was already an operational model design that was ready to be validated. Data analysis techniques adjust the research procedures designed, the data of this study are qualitative data, but in the distribution, there is data retrieval or using quantitative methods, simple calculations (descriptive statistics).

\section{Results}

The development of this teaching material shows that teaching materials are systematically developed according to the latest curriculum. Therefore in this initial stage this study found, the composition of teaching materials consists of theme titles, concept maps, appreciation, indicator activities, goals, independent assignments, group assignments, work, all-around language, self-employment, portfolio. The stage of expert test validation is should be based on validation. Therefore, this study would like to cover up some findings based validation and recommended , in this section

\subsection{Types of Teaching Materials}

According to Mulyasa (2006), the forms of teaching materials or learning materials include:

\subsubsection{Printed teaching materials}

Print teaching materials can be displayed in various forms. If the printed teaching material is well arranged, the teaching material will bring several advantages such as those proposed by Steffen Peter Ballstaedt, (1994) in Nurdyansyah, N. (2018). namely:

1). Written material usually displays a table of contents, making it easier for a teacher to show students which part is being studied.

2). The cost of procurement is relatively small.

3). Written materials are quickly used and can be moved easily.

4). The arrangement offers broad convenience and creativity for individuals.

5). The written material is relatively light and can be read anywhere.

6). Good teaching materials will motivate the reader to carry out activities, such as marking, taking notes, sketching.

7). Written material can be enjoyed as a document of great value.

8). Readers can set the tempo independently.

According to Bandono (2009), the preparation of printed teaching materials pay attention to the following matters:

- Display arrangement

- Easy language

- Test understanding

- Stimulants

- Ease of reading

- Instructional material

There are so many types of printed teaching materials that can be used in the learning process, including handouts, modules, textbooks, student 
activity sheets, models (mockups), posters and brochures.

\section{1) Handout}

According to Andi, Prastowo (2012) very concise learning material, sourced from several kinds of literature relevant to basic competencies and subject matter taught to students. In general, the handout serves to help students not need to take notes, as a companion to the educator's explanation, as reference material for students, motivating students to be more active in learning, reminders of the subject matter being taught, giving feedback and assessing learning outcomes.

\section{2) Modules}

Module is a book written with the aim that students can learn independently without or with the guidance of the teacher, so that the module contains at least about Instructions for learning (Instructions for students / teachers), Competencies to be achieved, Content or content, Supporting information, Exercises, work instructions, can be in the form of worksheets (LK), evaluations, feedback on the evaluation results. Learning with modules also allows students who have high speed in learning will more quickly complete one or more basic competencies compared to other students. It also increases the ability of students to learn on their own without being dependent on the presence of educators.

\section{3) Textbooks}

Textbooks, in general, are written material that presents the knowledge or ideas of the authors which are arranged systematically based on the applicable curriculum. Textbooks are useful to help educators in implementing the curriculum because it is structured based on the applicable curriculum, becomes the teacher's guide in determining teaching methods and provides opportunities for students to repeat lessons or learn new lessons.

\section{4) Student Activity Sheets}

Student work sheets are sheets containing assignments that must be done by students. Activity sheets are usually in the form of instructions or steps to complete a task. A task ordered in the activity sheet must be clear of the basic competencies to be achieved. LKS functions to minimize the role of educators and activate the role of students, making it easier for students to understand the material provided and rich in tasks to practice.

\section{5) Model (Mockup)}

Models (mockups) are teaching materials in the form of imitation of real objects to bridge various difficulties that can be found when presenting objects or objects directly into the class so that the original nuances of the objects can still be felt by students without reducing the original structure, so that learning becomes more meaningful.

\section{6) Brochures}

Brochures are written information material on a problem that is arranged systematically or printed which consists of only a few pages and folded without binding or printed leaflets containing brief but complete information about a company or organization (KBBI, Balai Pustaka, 1996 ) Thus, brochures can be used as teaching materials, during the presentation of brochures derived from basic competencies that must be mastered by students. Maybe brochures can be impressive teaching materials because they are attractive and practical. So that brochure sheets are not too many, then the brochure is designed to only contain one basic competency. Illustrations in a brochure will add to the interest of students to use them.

\section{7) Photos / Pictures}

Photos/images have better meaning compared to writing. Photos/pictures as instructional materials, of course, a good design is needed so that after finishing seeing a series of photos/images students can do something that ultimately masters one or more basic competencies. According to Weidenmann in the book, Lehren mit Bildmedien illustrates that seeing a photo/picture has a higher meaning than reading or hearing.

Through reading that can be remembered only $10 \%$, from hearing the remembered $20 \%$, and from seeing the remembered $30 \%$. Well-designed photos/images can provide a better understanding. This teaching material in using it must be assisted with written material. Written material can be in the form of instructions on how to use it and or test material.

\subsubsection{Listen to Materials (Audio)}

Audio teaching material is one of the non-printed teaching materials which contains a system that uses audio signals directly, which can be played or played by educators to their students to help them master certain competencies. These types of audio teaching materials include radio, MP3 tapes, MP4s, sounds recorders and mobile phones. This teaching material can store sounds that can be played repeatedly to students and is usually used for language and music lessons.

\subsubsection{Viewing Materials (Audiovisual)}

Learning material is a teaching material that combines two materials, namely visual and auditory. auditory material is intended to stimulate the sense of hearing while visual to stimulate the sense of sight. With a combination of both, educators can create a higher quality learning process. It is because students tend to be easier to remember and understand a lesson 
if they do not only use one type of senses, especially if only the senses of hearing. Instructional materials that listen can be able to show something that is initially impossible to see in the classroom to be seen. Besides that, it can also create visual effects that allow students to strengthen the learning process. Learning materials for hearing include video and film.

\subsubsection{Interactive Teaching Materials}

Interactive teaching materials are teaching materials that combine interactive learning media (audio, video, text or graphics) to control command or natural behavior of a presentation. Interactive teaching materials allow for a two-way relationship between teaching materials and users so that students will be encouraged to be more active.

Interactive teaching materials can be found in the form of interactive CDs, which in the process of making and using cannot be separated from computer devices. Therefore, interactive teaching materials also include computer-based teaching materials.

\subsection{Criteria for Good Teaching Materials}

Good and interesting teaching materials require writing that uses effective written expressions. A good written expression will be able to communicate messages, ideas, ideas, or concepts that are conveyed in teaching materials to the reader/user properly and correctly. Writing expressions can also avoid misinterpretation or understanding. Teaching materials given to students must be quality teaching materials. Quality teaching materials can produce quality students because students consume quality teaching materials. According to Furqon (2009) in good teaching materials must meet several criteria as follows:

- The substance discussed must include the body figure of the competency or sub-competence that is relevant to the profile of graduate ability.

- The substance discussed must be correct, complete and actual, covering the concepts of facts, procedures, terms and notations and arranged based on hierarchical / step mastery of competence.

- Level of readability, both in terms of language and substance difficulties, must be by the level of learning ability.

- The systematics for the preparation of teaching materials must be clear, coherent, complete and easy to understand.

Whereas in developing teaching materials, it must have several criteria as follows:

- Teaching materials must be relevant to the learning objectives
- Teaching materials must be by the level of child development.

- Good material is material that is useful for students both as a development of their knowledge and the need for future assignments in the field

- The material must attract and stimulate student activity

- The material must be arranged in a systematic, gradual and tiered manner

- Materials delivered to students must be comprehensive, complete and complete.

- Guidelines for Teachers who will direct all their activities in the learning process, as well as competency substances that should be taught/trained to their students.

- Guidelines for students who will direct all their activities in the learning process, as well as the substance of competence that should be learned.

- Tools for evaluating achievement of learning outcomes.

- Helping teachers in teaching and learning activities

- Helping students in the learning process

- As learning equipment to achieve lesson objectives

- To create a conducive learning atmosphere

Furthermore, the purpose of the preparation of teaching materials must be able to arouse students' learning passion, so that the teaching materials provided can be beneficial for students. Implicitly, teaching materials must also be able to become a means of increasing knowledge about language rules for students. Nevertheless, in reality, teachers need additional material to enrich students' knowledge of terminology in Indonesian, including abbreviations and acronyms. The addition and enrichment of three things in strengthening the rules of the Indonesian language is expected that students will be more competent in the use of rules in Indonesian.

\subsection{Definition of Terms}

The term is a word or phrase that is used as a name or symbol and which carefully expresses the meaning of concepts, processes, circumstances, or characteristics that are unique in the fields of science, technology, and art. The terminology is a set of principles and provisions for the formation of terms and a collection of terms that they produce. Terminology studies include the formation and relation of terms to a culture. The expert in terminology is called the interpreter of the term "terminologist" and is sometimes part of the field of translation. The terms in Indonesian are based on common Indonesian vocabulary, cognate language vocabulary, and foreign language vocabulary. For example, democracy, capital markets, equity, electron traps. Implicitly, teaching materials must also be capable. 


\subsubsection{Types of Terms}

a) The general term is a term that originates from a particular field, which, because it is widely used, becomes an element of general vocabulary. For example, budget, power, marriage, judgment, piety.

b) Special terms are terms whose meanings are limited to certain fields. For example, appendectomy, bipatride, kurtosis, Pleistocene.

\subsubsection{Good Terms of Formation}

In the term formation, it is necessary to pay attention to the requirements in the use of the following Indonesian vocabulary

a) The term chosen is the most appropriate word or phrase to express the intended concept, and that does not deviate from that meaning.

b) The term chosen is the shortest word or phrase among the choices available that have the same reference.

c) The term chosen is a word or phrase that has a good sense (connotation).

d) The term chosen is a euphonic word or phrase.

e) The term chosen is a word or phrase that forms according to the rules of Indonesian.

\subsubsection{Name and Nomenclature}

Names are words or phrases that are based on an agreement to become identification objects, people, animals, plants, places, or things. Nomenclature (nomenclature) is a set of naming rules in a particular field of science, such as chemistry and biology, along with a collection of names that they produce. For example aldehyde, sodium chloride, primate, Oryza sativa.

\subsubsection{Term Formation Process}

The term formation process is carried out through matching or translation, for example, the busway becomes a bus lane, the absorption of foreign vocabulary, for example, a camera becomes a camera and a combination of translation and absorption, for example, subdivision becomes a subdivision.

\section{a. The Science and Terminology Concept}

The efforts of scholars (scientist) have and continue to produce scientific concepts, the disclosure of which is poured in terminology devices. There are terms that are already established, and there are also terms that still need to be created. The scientific concepts that have been produced by scientists and Indonesian pandits naturally have an established term. However, most modern scientific concepts learned, used, and developed by actors in science and technology in Indonesia come from abroad and have been symbolized by foreign language terms. Also, it is possible that the activities of scientists and Indonesian pandits will spark a completely new concept of science, technology and art so that the creation of new terms will be needed.

\section{b. Indonesian term raw materials}

No single language already has a complete vocabulary and does not require an expression for its new ideas, findings, or references. English which is now considered the main international language, for example, once absorbed words and expressions from Greek, Latin, French, and other languages, which numbered almost three-fifths of their vocabulary. In line with that, Indonesian term material is taken from various sources, especially from three important language groups, namely

- Indonesian, including its absorption, and Malay,

- allied Nusantara languages, including old Javanese,

- $\quad$ foreign languages, such as English and Arabic.

\subsubsection{Establishment of the Archipelago Terms}

The term that expresses the concept of excavation by scientists and Indonesian pandits, such as Bhinneka Tunggal Ika, Batik, Banjar, Sawer, Gunungan, and Pamor, has long been widely accepted so that it can be consolidated and the results codified.

\subsubsection{Term Matching}

Matching foreign terms into Indonesian, and if necessary to one cognate language, is carried out through translation, absorption, or a combination of translation and absorption. For the sake of uniformity, the preferred source of reference is the English term whose use is international because it has been approved by experts in their fields. Writing the term absorption is done with or without spelling adjustments based on phonotactic rules, namely the sound sequence relationship permitted in Indonesian.

\subsubsection{Translation with Sensitivity}

Sometimes efforts to match foreign terms need to be done by creating new terms. The term factoring, for example, is difficult to translate or be absorbed in its entirety. In the treasures of Indonesian / Malay vocabulary, there are forms of factoring and accounts that describe the transfer of debt collection rights. Then, the term factoring piu-tang is designed as the equivalent of the factoring term. Likewise, catering matching is a food service, and invention is a creation obtained through recording.

\subsubsection{Glossary Absorption}

Absorption of foreign terms to become an Indonesian term is carried out based on the following things.

a) Foreign terms that will be absorbed increase the interrelation of foreign language and Indonesian language (intertranslatability) given future needs. 
b) Foreign terms to be absorbed make it easier to understand foreign texts by Indonesian readers because they are known first.

c) Foreign terms to be absorbed are more concise when compared to Indonesian translation.

d) Foreign terms that will be absorbed make it easier for interpersonal agreements if the equivalent translation is too many synonyms.

e) Foreign terms that will be absorbed are more suitable and appropriate because they do not contain bad connotations.

The process of absorption of foreign terms, by prioritizing the visual form, is carried out in the following way.

a). Absorption with spelling and pronunciation adjustments For example:

- Camera - camera

- Microphone - microphone

- Systems - systems

b). Absorption with spelling adjustments without pronunciation adjustments For example:

- Design - design

- Files - files

- Science - science

c). Absorption without spelling adjustments, but with pronunciation adjustments For example:

- Bias - bias

- Nasal - nasal

- Radar (radio detecting and ranging) - radar

d). Absorption of terms without spelling and pronunciation adjustments is done if the term is also widely used in general vocabulary, the term is not written in italics (printed with upright letters). For example:

- Golf - golf

- Internet - internet

- Lifts - elevators

\subsubsection{Standardization and Codification of Terms}

The terms selected through consolidation, translation, absorption, and creation are standardized through codification that seeks orderliness according to the rules and customs of language use. The codification was achieved by the arrangement of the spelling system, the grammar book, and the dictionary that recorded and determined the standard form.

\subsubsection{Standardization and Codification of Terms}

The terms selected through consolidation, translation, absorption, and creation are standardized through codification that seeks orderliness according to the rules and customs of language use. The codification was achieved by the arrangement of the spelling system, the grammar book, and the dictionary that recorded and determined the standard form.

\subsubsection{Procedure and nomenclature}

The term arrangement is a set of rules for the formation of terms and a collection of terms that they produce. The nomenclature of the term is a set of rules naming several branches of science such as chemistry and biology along with a collection of names that they produce.

\subsubsection{General terms and special terms}

The general term is a term originating from a particular field which is widely used as a common vocabulary element. Special terms are terms whose meanings are limited to certain fields. There are several requirements for using Indonesian vocabulary:

a) The term chosen does not deviate from the meaning and must express the concept in question.

b) The terms chosen must be short among the choices available that have the same reference.

c) The term chosen has a good sense of value (connotation).

d) The term chosen is as audible or euphonic.

e) The terms chosen must be by the rules of Indonesian that are good and correct.

\subsubsection{Semantic Aspects of Terminology}

a) Giving New Meanings

That is, the word can be reduced or added to its meaning so that its application is narrower or wider. An example is the narrowing of meaning and expansion of meaning.

b) The term of Synonym

Two or more terms whose meanings are the same or similar, but the forms are different. micro-as a micro-equivalent in certain cases better than microscopic.

c) The term of Homonym

The term homonym is two terms, or more, the same as spelling and pronunciation, but the meaning is different because the origin is different. The term homonym can be divided into:

1) Homograph, The term homograph is the same term as spelling, but different pronunciation.

For example terrace-core $=$ flat floors in front of the house

2) Homophones, the term homophones is the same term as pronunciation, but different in spelling.

For example a bank with abang

3) Polysemy, The term polysemy is a form that has a double meaning related.

For Examples: (cushion) head - hat (stake) 


\subsubsection{Definition of Abbreviations}

The abbreviation is a shortened form consisting of one or more letters. While the acronym, is an abbreviation in the form of a combination of initial letters, a combination of syllables, or a combination of letters and syllables from a series of words that are treated as words. Especially for the formation of an acronym, it should pay attention to the following conditions:

a) The number of acronym syllables should not exceed the number of common syllables in the Indonesian word.

b) Acronyms are formed by heeding the harmonious combination of vocals and consonants by the usual Indonesian word pattern.

The guideline for the formation of abbreviations and acronyms is regulated in the Decree of the Minister of Education and Culture of the Republic of Indonesia Number 0543a / U / 198, September 9, 1987, concerning General Guidelines for Improved Indonesian Spelling (anonymous, 2010).

\subsubsection{Abbreviation}

In writing, abbreviations are governed by several rules as follows:

a) Abbreviation of the name of the person, name of the title, address, position or rank followed by a period. For example:

Muh. Yamin

Suman Hs.

M.B. A. (master of business administration)

M.Sc. (master of science)

S.Pd. (Bachelor of Education)

Mr. (father)

Bro. (you)

Cabbage. (Colonel)

b) Abbreviation of the official name of a government institution and state administration, body or organization, and the name of an official document consisting of the initial letters of a word written in capital letters and not followed by a period. For example:

MPR (House of Representatives)

PGRI (Republic of Indonesia Teacher Association)

KTP (Identity Card)

c) Common abbreviations consisting of three letters or more followed by one point. For example:

etc. (etc.)

p. (page)

sda. (same as above)

d) Common abbreviations were consisting of two letters, each letter followed by a point. For example: d.a. (by address)

u.b. (for him)

u.p. (for attention)

e) Chemical symbols, abbreviations for units of measure, measure, scale, and currency not followed by periods. For example:

$\mathrm{Cu}$ (copper)

$\mathrm{Cm}$ (centimetre)

1 (litre)

kg (kilograms)

IDR (rupiah)

\subsubsection{Acronyms}

a) Acronym of self-name in the form of a combination of the initial letters of the word series written entirely in capital letters. For example:

ABRI (Armed Forces of the Republic of Indonesia) LAN (Institute of Public Administration)

SIM (driver's license)

b) The acronym of self-name in the form of a combination of syllables or a combination of letters and syllables from the word series written in the initial letter of capital letters. For example:

Akabri (Indonesian Armed Forces Academy) Iwapi (Indonesian Women's Business Association)

Sespa (Administrative Staff Staff School)

Scout (Praja Muda Karana)

c) Acronyms that open self-names in the form of combinations, syllables, or combinations of letters and syllables from word series are written entirely in lowercase letters. For example:

election (general election)

rapim (leadership meeting)

missiles (missiles)

ticket (proof)

violation)

\section{Conclusions and Recommendation}

Teaching materials are a set of materials that are arranged systematically, both written and not to create an environment / atmosphere that allows students to learn (Ministry of National Education, 2008). This ongoing study aims to share its findings in its initial stage. The instruments used for data collection in this study were school documentation and internet library research seems helps a lot in defining and scouting the numerous data can be used. The results of this study indicate that: (1) teaching materials are should be designed in line with the 2013 curriculum based on printed, video and audio material, (2) the criteria should highlighted the essence of relevance, readability, and systematic (3) There are 16 related terms issues reveals in this study regarding Language teaching material revealed in this study a.n. (On behalf of the) 
Therefore, the development of terminology-based Indonesian language materials, validity of terminology-based Indonesian language teaching materials, constraints faced in developing terminology-based Indonesian language teaching materials in these series of issues can be extended to numerous issues of research after this for example in a specific context such as: (1) the development of terminology-based Indonesian language materials for students in Deli Serdang, (2) the level of validation of terminology-based Indonesian language materials for students in Deli Serdang, (3) students' responses related to the legibility of terminology-based Indonesian language materials.

The development of this teaching material shows that teaching materials are systematically developed, in line with the 2013 curriculum. The composition of teaching materials consists of theme titles, concept maps, appreciation, indicator activities, goals, independent assignments, group assignments, work, all-around language, self-employment, portfolio. The stage of expert test validation is based on validation.

\section{Acknowledgement}

This research was supported by the Universitas Muslim Nusantara Al-Wasliyah under internal research scheme. Therefore, the authors would like to express their sincere gratitude. However, any opinions, findings, and conclusions or recommendations expressed in this material are those of the authors and do not necessarily reflect the views of the respected institution.

\section{References}

Abbas, M. F. F. (2018). Solving the students'problems in writing argumentative essay through collaborative writing strategy. English review, 7(1).

Ali, A. (2010). Empowering teachers through capacity building and professional development: a collaborative effort.

Al-Qinai, J. (2007). Abbreviation and acronymy in English Arabic translation. Meta: Journal des traducteurs/Meta: Translators' Journal, 52(2), 368-375.

Ariyatna, E. (2018). Pengembangan Bahan Ajar Menulis Teks Cerita Ulang Biografi Berbasis Peta Pikiran Siswa Kelas XI SMK NEGERI 2 MEDAN (Doctoral dissertation, UNIMED).

Bahasa, P. (1989). Pedoman umum pembentukan istilah. Balai Pustaka.

Bahasa, P. (2008). Departemen Pendidikan dan Kebudayaan. Kamus Besar Bahasa Indonesia.
Borg, W. R., \& Gall, M. (1989). D.(1989). Education Research: An Introduction (4th Edition). New York. Longman publisher.

Butler, C. (1995). Statistika dalam Linguistik. Bandung: Penerbit ITB.

Buus, N., \& Hamilton, B. E. (2016). Social science and linguistic text analysis of nurses' records: a systematic review and critique. Nursing inquiry, 23(1), 64-77.

Deliani, S. Pengaruh Kosakata Bahasa Jawa Dalam Surat Kabar Di Medan (Master's thesis).

Deliani, S., Sulistyawati, S., \& Kurniawan, B. (2018, April). Pembentukan Karakter Melalui Literasi dari Aspek Satra dan Budaya di Desa Manik Maraja Kec Sarimatondang Kabupaten Sidamanik. In PROSIDING SEMINAR NASIONAL HASIL PENGABDIAN (Vol. 1, No. 1, pp. 356-360).

Departemen Pendidikan Nasional. (2005). Kamus Besar Bahasa Indonesia Edisi Ketiga. Jakarta.

Dewi, H. D. (2017). Language Acquisition and Translator Training. Journal of English Language and Culture, 1(2).

Furqon J. (2009). Teacher certification in Indonesia: A strategy for teacher quality improvement. Departemen Pendidikan Nasional, Republik Indonesia.

Hamdani. (2017). Strategi Belajar Mengajar. Bandung: CV. Pustaka Setia.

Hans, N. (2012). Comparative education: A study of educational factors and traditions. Routledge.

Hasibuan, A. M., Saragih, S., \& Amry, Z. (2018). Development of Learning Materials Based on Realistic Mathematics Education to Improve Problem Solving Ability and Student Learning Independence. International Electronic Journal of Mathematics Education, 14(1), 243-252.

Kosasij, E. (2014). Jenis-jenis Teks dalam Mata Pelajaran Bahasa Indonesia SMA/MA/SMK. Bandung: Yrama Widya.

Kuraedah, S., Gunawan, F., Wekke, I. S., \& Hamuddin, B. (2018, July). Learning Environment Construction in Islamic Higher Education: Connecting the Puzzles of Ideas. In IOP Conference Series: Earth and Environmental Science (Vol. 175, No. 1, p. 012107). IOP Publishing.

Mulyasa, E. (2006). Kurikulum Berbasis Kompetensi, Konsep, Karakter, dan Implementasi. Bandung: PT. Remaja Rosdakarya.

Nikolov, M. (Ed.). (2016). Assessing young learners of English: Global and local perspectives. Berlin: Springer. 
Nurdyansyah, N. (2018). Pengembangan Bahan Ajar Modul Ilmu Pengetahuan Alambagi Siswa Kelas Iv Sekolah Dasar. Universitas Muhammadiyah Sidoarjo.

Peersman, C., Daelemans, W., Vandekerckhove, R., Vandekerckhove, B., \& Van Vaerenbergh, L. (2016). The effects of age, gender and region on non-standard linguistic variation in online social networks. arXiv preprint arXiv:1601.02431.

Prastowo, A. (2012). Pengembangan Sumber Belajar. Yogyakarta: Pedagogia.

Spolsky, B. (Ed.). (2012). The Cambridge handbook of language policy (p. 46). Cambridge: Cambridge University Press.

Sudjana, N. (2005). Metode statistika. Bandung: Tarsito, 168.

Weidenmann, B. (1991). Lernen mit Bildmedien: psychologische und didaktische Grundlagen. Beltz.

Wekke, I. S., Yandra, A., \& Hamuddin, B. (2017, December). Learning Strategy in Class Management: A Reflection from Manado Case. In IOP Conference Series: Earth and Environmental Science (Vol. 97, No. 1, p. 012053). IOP Publishing.

Yule, G. (2016). The study of language. Cambridge university press. 